E3S Web of Conferences 1, 41007 (2013)

DOI: $10.1051 / \mathrm{e} 3$ sconf/20130141007

(c) Owned by the authors, published by EDP Sciences, 2014

\title{
Investigation of Polluted Zones by Lead in North West of Iran
}

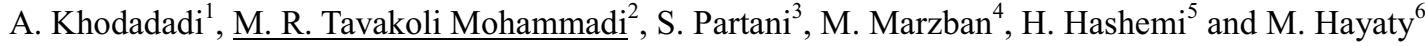 \\ 1 Assoc. Prof. of Environmental Engineering, Modares Environmental Research Center (MERC), Tarbiat Modares \\ University, Tehran, Iran, \\ ${ }^{2}$ PhD Student of Mining Engineering, Tarbiat Modares University, Tehran, Iran, ${ }^{3}$ Department of Civil Engineering, \\ Central Tehran Branch Islamic Azad University of Iran, PhD Student of Civil-Water Engineering, University of Tehran, \\ Tehran, Iran, ${ }^{4}$ Msc Student of Mineral Processing, Tarbiat Modares University, Tehran, Iran, \\ ${ }^{5}$ Msc Student of Civil Engineering, Tarbiat Modares University, Tehran, Iran, \\ ${ }^{6}$ PhD Student of Mining Engineering, Sharood University of Technology, Sharood, Iran,
}

\begin{abstract}
National project of Important Heavy Metals Identification of Iran (IHMI), following the UNDP and supported by Department of Environment of Iran (DOE), has been completed by Modares Environmental Research Center (MERC). Due to this project the pollution potential sources was investigated by overall distribution maps of any parameters that may cause the lead pollution. Then the sampling points was determined by some geo-statistical analysis and the sampling process was done according to standard methods of sampling, preserving, transferring to lab, measuring and analyzing etc through the 3 months in three phases of materials (effluent and discharges, solid waste, water, soil and sediment samples from natural sources like river etc.). After gathering the final results, overlaying the potential sources and polluted positions (according to violation of national and international standards of sampled points) by Geographic Information Systems (GIS) led the research to closing to the pollutant sources in north west provinces (Eastern Azerbaijan, Western Azerbaijan, Ardabil and Zanjan). The synthetic and natural pollution sources observed were 17 and 20 respectively. Abir River, Niroo Gostar Taban Industrial Complex and Copper Industries were the most important pollution sources in material phases of Natural, effluent and solid waste respectively.
\end{abstract}

Keywords: Environment, Heavy Metals, Lead, GIS, Natural and Synthetic Pollution Sources

\section{Introduction}

The past 200 years has seen a rapid increase in population's worldwide resulting in the Need for even greater amounts of fuel and development of industrial chemicals, fertilizers, pesticides, and pharmaceuticals to sustain and to improve quality of life. Although many of these chemicals are utilized or destroyed, a high percentage are released into the air, water and soil, representing a potential environmental hazard Each pollutant category can impact more than one medium and each category can represent more than one process or member, e.g. the trace elements comprise more than 20 different elements (e.g. $\mathrm{Pb}, \mathrm{Cd}, \mathrm{Zn}, \mathrm{Cu}, \mathrm{Fe}, \mathrm{Ni}, \mathrm{Mn}, \mathrm{Hg}$ etc.) During the last two decades there has been a great progress in defining major anthropogenic and natural sources of $\mathrm{Cd}, \mathrm{Pb}$ and other heavy metals (Nriagu and Pacyna, 1988).

Estimates made by Nriagu and Pacyna (1988) suggest that soils are receiving large quantities of heavy metals from disposal of a variety of industrial wastes. The two principal sources of heavy metals in soils worldwide are however, the disposal of ash residues from coal combustion and the general wastage of commercial products on land. Urban refuse represents an important source of $\mathrm{Cu}, \mathrm{Hg}, \mathrm{Pb}$, and $\mathrm{Zn}$ with notable contributions of $\mathrm{Cd}, \mathrm{Pb}$, and $\mathrm{V}$ also coming via the atmosphere. The large volumes of wastes associated with animal husbandry, logging, as well as agricultural and food production can affect the heavy metal budget of many soils significantly. Although municipal sewage sludge may not be particularly important source on a global scale, it can be one of the most important sources of metal contamination of soils on a local scale. A global 
Table 1. Estimated natural and anthropogenic global emissions of trace metals to the atmosphere for selected elements (Nriagu and Pacyna, 1988).

\begin{tabular}{|c|c|c|c|}
\hline Element & $\begin{array}{c}\text { Natural } \\
(\mathrm{kt} / \text { year})\end{array}$ & Anthropogenic (kt/year) & $\begin{array}{c}\text { Approx. ration } \\
\text { Anthropogenic/natural }\end{array}$ \\
\hline Arsenic & $1.1-33.5$ & $12.0-25.6$ & 1 \\
\hline Cadmium & $0.1-3.9$ & $3.2-12.0$ & 1 \\
\hline Copper & $2.2-53.8$ & $19.7-50.8$ & 27 \\
\hline Lead & $0.9-23.5$ & $287.5-376.0$ & 2 \\
\hline Mercury & $\sim 2$ & $3.5-4.5$ & 3 \\
\hline Selenium & $0.7-18.1$ & $1.7-5.8$ & 3 \\
\hline Vanadium & $1.6-54.2$ & $30.0-141.8$ & \\
\hline Zinc & $4.0-85.9$ & $70.4-193.5$ & \\
\hline
\end{tabular}

Table 2. Lead pollution and potential contaminant sources in North West of Iran

\begin{tabular}{|c|c|c|c|c|c|c|}
\hline $\begin{array}{l}\text { Province } \\
\text { Name }\end{array}$ & Source Type & $\begin{array}{l}\text { Standard } \\
\text { Limit }\end{array}$ & $\begin{array}{l}\text { Zone } \\
\text { No. }\end{array}$ & $\begin{array}{c}\text { Name of Polluted } \\
\text { Zone }\end{array}$ & $\begin{array}{l}\text { Pollutant } \\
\text { Cons. }\end{array}$ & Situation \\
\hline \multirow{4}{*}{ Ardabil } & Effluent & $1 \mathrm{ppm}$ & - & - & - & Not Polluted \\
\hline & Solid Waste & $750 \mathrm{mg} / \mathrm{kg}$ & $\mathrm{I}-12$ & $\begin{array}{c}\text { Leather } 422, \\
\text { Khalkhal }\end{array}$ & 4272.775 & $\begin{array}{l}\text { Potentially } \\
\text { Polluted }\end{array}$ \\
\hline & \multirow{2}{*}{ Natural } & \multirow{2}{*}{$0.001 \mathrm{ppm}$} & $\mathrm{N}-9$ & Hirochay River & 0.057 & Polluted \\
\hline & & & $\mathrm{N}-7$ & Balkhrood river & 0.056 & Polluted \\
\hline \multirow{4}{*}{ East Azarbaijan } & Effluent & $1 \mathrm{ppm}$ & $\mathrm{I}-140$ & $\begin{array}{l}\text { Azarbaijan } \\
\text { Coating and } \\
\text { Plating }\end{array}$ & 0.875 & $\begin{array}{l}\text { Potentially } \\
\text { Polluted }\end{array}$ \\
\hline & \multirow[t]{2}{*}{ Solid Waste } & \multirow[t]{2}{*}{$750 \mathrm{mg} / \mathrm{kg}$} & I-129 & $\begin{array}{c}\text { Simab Coating } \\
\text { and Plating } \\
\text { Tabriz }\end{array}$ & 5210 & Polluted \\
\hline & & & $\mathrm{I}-135$ & Moto-Jen & 1612.800 & Polluted \\
\hline & Natural & $0.001 \mathrm{ppm}$ & $\mathrm{N}-2$ & Jolfa River & 0.067 & Polluted \\
\hline \multirow{5}{*}{ West Azarbaijan } & Effluent & $1 \mathrm{ppm}$ & $\mathrm{I}-47$ & $\begin{array}{c}\text { Niroo Gostare } \\
\text { Taban Unit }\end{array}$ & 3.143 & Polluted \\
\hline & \multirow[t]{2}{*}{ Solid Waste } & \multirow[t]{2}{*}{$750 \mathrm{mg} / \mathrm{kg}$} & M-2 & $\begin{array}{c}\text { Zarshouran Gold } \\
\text { Mine Tail Dam }\end{array}$ & 2786.750 & Polluted \\
\hline & & & $\mathrm{I}-17$ & Uromieh Cement & 987.500 & Polluted \\
\hline & \multirow[b]{2}{*}{ Natural } & \multirow[b]{2}{*}{$0.001 \mathrm{ppm}$} & N-19 & Bukan River & 0.057 & Polluted \\
\hline & & & $\mathrm{N}-20$ & $\begin{array}{c}\text { Shahin Dejh } \\
\text { River }\end{array}$ & 0.038 & Polluted \\
\hline \multirow{4}{*}{ Zanjan } & Effluent & $1 \mathrm{ppm}$ & - & - & - & Not Polluted \\
\hline & Solid Waste & $750 \mathrm{mg} / \mathrm{kg}$ & $\mathrm{I}-85$ & $\begin{array}{c}\text { Copper } \\
\text { Industries }\end{array}$ & 9293.750 & Polluted \\
\hline & \multirow{2}{*}{ Natural } & \multirow{2}{*}{$0.001 \mathrm{ppm}$} & $\mathrm{N}-9$ & Abir River & 0.090 & Polluted \\
\hline & & & $\mathrm{N}-1$ & Dandi River & 0.086 & Polluted \\
\hline
\end{tabular}

assessment of natural sources of atmospheric heavy metals has been made by Nriagu and pacyna (1988). Biogenic sources can account on average for over $50 \%$ of $\mathrm{Se}, \mathrm{Hg}$, and $\mathrm{Mo}$, and from 30 to $50 \%$ of the $\mathrm{As}, \mathrm{Cd}, \mathrm{Cu}$, $\mathrm{Mn}, \mathrm{Pb}$, and $\mathrm{Zn}$, released annually to the atmosphere from natural sources. Volcanic emanations can account for 40 to $50 \%$ of the $\mathrm{Cd}$ and $\mathrm{Hg}$ and 20 to $40 \%$ of the As, $\mathrm{Cr}, \mathrm{Cu}, \mathrm{Ni}, \mathrm{Pb}$, and $\mathrm{Sb}$ emitted annually from natural sources. Finally, soil-derived dusts can account for over 50 percentage of the total $\mathrm{Cr}, \mathrm{Mn}$, and $\mathrm{V}$ emissions, as well as for 20 to $30 \%$ of the $\mathrm{Cu}, \mathrm{Mo}, \mathrm{Ni}, \mathrm{Pb}, \mathrm{Sb}$, and $\mathrm{Zn}$ released annually to the atmosphere. Table 1 compares natural and anthropogenic emissions of trace elements.

A comparison of the worldwide emissions of heavy metals from natural and anthropogenic sources suggests that human activities generate emissions of heavy metals in such quantities that they significantly exceed emissions from natural sources. For $\mathrm{Pb}, \mathrm{Cd}$ and $\mathrm{Hg}$ the global anthropogenic emissions exceed global natural emissions by factors of 27, 4 and 2 respectively (Nriagu and Pacyna, 1988).

In this direction, Modares Environmental Research Center (MERC) of Tarbiat Modarres University has implemented a national project to identify the heavy metal pollution sources in northwestern provinces of Iran under the auspices of Environmental Protection Organization. In this project, pollution sites and potentials were identified in field studies. Within three 
months, various solid and liquid phases of it including wastewater, solid waste and effluent resources were subject to sampling and measurement. Then, using GIS, the data related to identifying the sites contaminated with heavy metals in the provinces under study (West Azerbayejan, East Azerbayejan, Ardebil and Zanjan) were subject to analysis in comparison with national and global standards (Khodadadi, 2009). The aim of this study was stating the results of this research in relation to heavy metal of lead.

\section{Methods and Materials}

\section{Sampling, Preparation and Measurement Operations}

The USGS sampling standard was used for sampling the liquid (wastewater and effluent) and solid (solid waste) samples of the various samples identified (Carr and Neary, 2008). For liquid samples, $\mathrm{pH}$ was measured, and if higher than 7 , dilute nitric acid was used to avoid likely precipitates or return of the sample to liquid phase. The aqueous samples were then filtered and transferred to laboratory in $250 \mathrm{ml}$ polyethylene containers for analysis. After drying, the solid and sludge samples were grinded, and the materials passing the 200 mesh were digested before feeding into the measuring instrument. In the laboratory, to measure the concentration of metals, ICP instrument was used with measuring precision in $\mathrm{ppb}$ level.

\section{Identification and Analysis of Polluted Zones in Studied Province}

Generally the main goals of GIS maps preparing, are preparing the pollution sources and potential distribution maps in Iran and environmental monitoring program for contaminants industries.

In the next stages the sampling and measurements results was allocated to the sample points on maps and the standards violations and quantitative comparison was created by dome bar diagrams and colour ID on the maps.

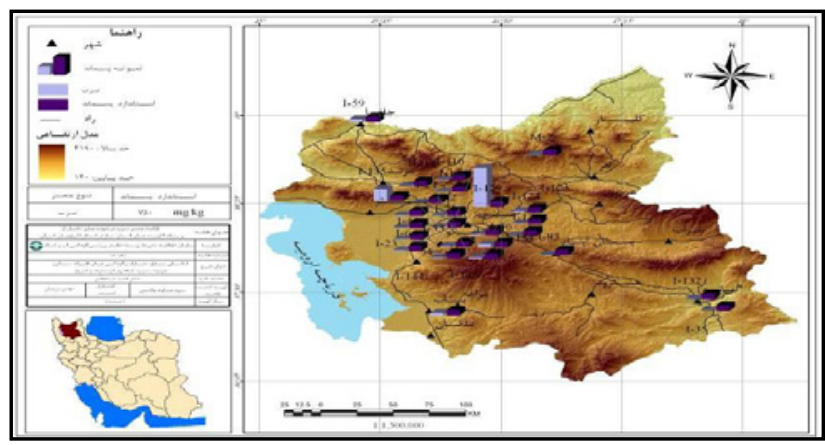

Fig. 1. Lead concentration in solid waste samples from synthetic sources at E. Az. province.

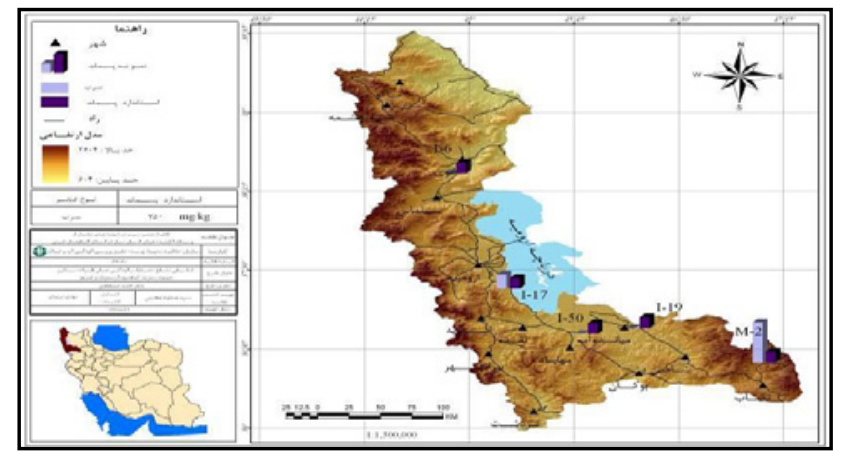

Fig. 2. Lead concentration in solid waste samples from synthetic sources at W. Az. province.

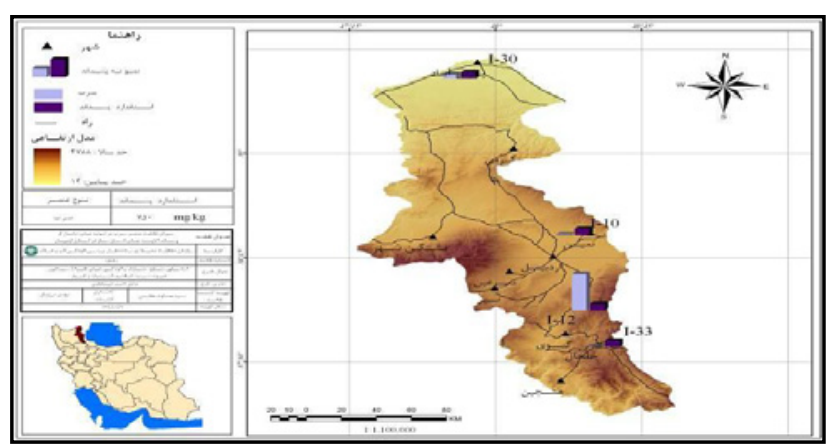

Fig. 3. Lead concentration in solid waste samples from synthetic sources at Ardabil province.

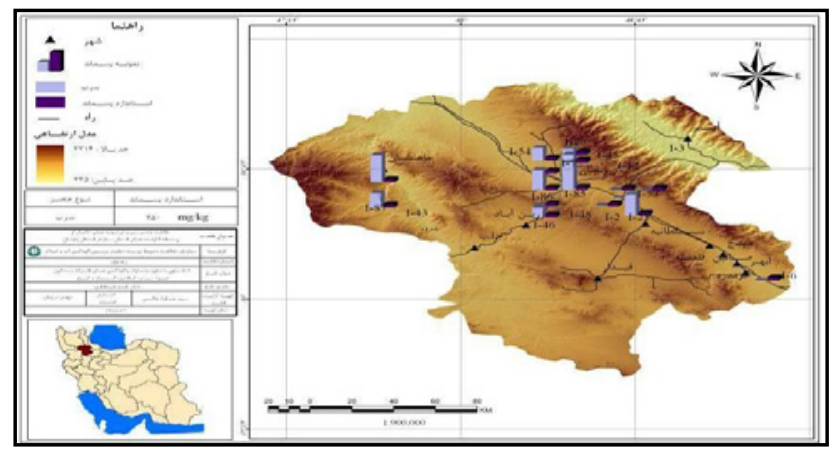

Fig. 4. Lead concentration in solid waste samples from synthetic sources at Zanjan province.

So that focusing the pollution sources, the mitigation measures and environmental management plan and monitoring program were developed (Khodadadi, 2009). 154 points were sampled and analysed overall in the mentioned provinces which some the pollutant sources results have been presented in Table 2.Some sampled points and lab analyzed results have been showed as Figures 1-4.

\section{Conclusions}

Since Lead is one of the most dangerous heavy metals which the wide spectrum of diseases caused by it, has 
been the subject of numerous scientific research.

So, National project of Important Heavy Metals Identification of Iran (IHMI), following the UNDP and supported by Department of Environment of Iran (DOE), has been completed by Modares Environmental Research Center (MERC).

Through this research results from 154 points were sampled in four provinces, 37 pollution sources were ditected which Abir River, Niroo Gostar Taban Industrial Complex and Copper Industries were the most important pollution sources in material phases of Natural, effluent and solid waste respectively.

\section{Acknowledgement}

The authors wish to thank Modares Environmental Research Center (MERC) of Tarbiat Modarres University and Environmental Organization of Iran for providing the possibility of conducting this research.

\section{References}

Carr GM, Neary, JP. Water quality for ecosystem and human health. $2^{\text {nd }}$ Edition, United Nations Environment Programme Global Environment Monitoring System (GEMS)/Water Programme, 2008.

Khodadadi A. National project of important heavy metals identification of Iran (IHMI), following the UNDP and supported by Department of Environment of Iran (DOE), Modares Environmental Research Center (MERC), 2009.

Nriagu JO, Pacyna JM. Quantitative assessment of worldwide contamination of the air, water and soils with trace metals, Nature (London), 333, 134-139, 1988. 